\title{
Economics of Wheat Cultivation in Jaunpur and Ghazipur districts of Eastern Uttar Pradesh
}

\author{
Ramratan Singh $^{1 *}$, Babu Singh ${ }^{1}$, Jyoti Gupta $^{2}$ and Ramvinay Pal ${ }^{3}$ \\ ${ }^{1}$ Department of Agriculture Economics, ${ }^{2}$ College of Home Science, ${ }^{3}$ Agriculture Extension, \\ C. S. Azad University of Agriculture and Technology, Kanpur, U.P.-208002, India \\ *Corresponding author
}

\section{A B S T R A C T}

\section{Keywords}

Cost, Benefit cost ratio, Gross income, Family labour income, Farm business income, Farm investment income

\section{Article Info}

Accepted: 17 September 2020 Available Online: 10 October 2020
The present study was conducted in Jaunpur and Ghajipur districts of Eastern U.P. District Jaunpur and Ghazipur were purposively selected and the two blocks from each district namely Mariyahun and Bkhsa from Jaunpur districts and from Ghazipur district Zamaniya and Saidpur were selected purposively for the study due to having highly concentration on wheat cultivation. List of the villages from selected blocks were prepared along with hectarage under wheat cultivation and 5 villages were selected randomly for study. In all 200 number of farmers were selected proportionally from each category of farmers and classified into three categories i.e. marginal (below 1 ha), small (1-2 ha), large ( 2 ha \& above). The period of enquiry pertain to the agricultural year 2016-17. The primary data were collected from 200 sample respondents (100 small, 70 small and 30 large) through pre-tested interview schedule. The present study has been made to work out the cost of cultivation, profitability and production of wheat. The cost of cultivation was found to be highest on large farm Rs/ha 56542.27 as compared to medium farm Rs/ha 53431.12 and small farm Rs/ha 49900.00. The gross income received from wheat cultivation was to be Rs/ha 92406.25 per hectare on overall farms, while gross income was found to be maximum in case of large farm Rs/ha 99656.25 followed by medium farm Rs/ha 93187.50 and small farm Rs/ha 84375.00. The net income, family labour income, farm business income and farm investment income were found to be Rs/ha 39115.09, Rs/ha 42556.76, Rs/ha 69555.42 and Rs/ha 66113.75 per hectare, respectively on overall farms. The benefit cost ratio was found to $1: 1.73$ on overall basis. The cost according to different cost concept on overall basis was as fallows, cost $\mathrm{A}_{1}, \mathrm{~A}_{2}, \mathrm{~B}_{1}, \mathrm{~B}_{2}, \mathrm{C} 1, \mathrm{C} 2, \mathrm{C}_{3}$ were observed to Rs. 22850.83, Rs. 22850.83, Rs. 35849.49, Rs. 49849.49, Rs. 39291.16 , Rs. 53291.16 and Rs. 58620.27 on sample farms respectively

\section{Introduction}

Wheat is a crop of worldwide importance. This crop is grown in various environments. It is the staple food of millions. Wheat is cultivated on about one-sixth of the total agricultural land in the world. Although paddy is mainly cultivated in Asia, wheat is still grown in all the peninsulas of the world. It provides about 20 percent of dietary calories for the world's growing population. . India is the second largest producer of wheat 
after China. Wheat has a special place among food crops.

In India, wheat covers an area of 30.79 million hectares having a production of 98.51 million tonnes with a productivity of 3200 kilogram per hectare in 2016-17 (Directorate of Economics \& Statistics 2018). Uttar Pradesh is the highest wheat producing state. During, 2016-17, area under wheat in U.P. was 9.66 million hectares and production was 30.06 million tonnes while productivity was $3113 \mathrm{kilogram} / \mathrm{ha}$ (Directorate of Economics \& Statistics 2018). Jaunpur and Ghazipur districts were also an important wheat producing districts of U.P. in the year, 20162017. The area under wheat in the district Ghazipur was reported as 154945 hectare with production of 317054 metric tonnes, while productivity was $21.47 \mathrm{Qtl} / \mathrm{ha}$ and area, production and productivity in Jaunpur district was 143398 hectare, 359403 metric tonnes and 23.42 Qtl/ha respectively (Shankhyakiya Patrika Janapad Ghazipur and Jaunpur, 2016-17). The study entitled "Economics of wheat cultivation in Jaunpur and Ghazipur districts of Eastern Uttar Pradesh" following objective: To work out the cost of cultivation and input: output relationship in production of wheat crop.

\section{Materials and Methods}

The research methodology adopted for the present study may broadly be divided under for sub-heads. (1) Sampling techniques, (2) Period of inquiry, (3) Analytical tools and (4) Cost concepts.

\section{Sampling technique}

A multistage sampling technique will be used to select the District, Blocks, Villages and Farmers. Two districts namely Jaunpur and Gazipure were selected purposely from Varanasi division of Eastern U.P. A list of all development blocks of the selected district Jaunpur and Gazipur were prepared. Among the 37 development blocks of Jaunpur and Gazipur, two blocks from each district was selected purposely for the study purpose, because these blocks are highly concentrated on wheat production. A list of all the villages of the selected blocks was prepared with the help of selected block headquarters. Then, 5 villages were selected randomly from each block, thus a total of 20 villages were selected from the four blocks. 10 respondents were selected randomly on the list of farmer engaged in wheat production from each village thus a total number of 200 respondents were interviewed on the prepared in advance schedule.

Period of enquiry- The data was pertain to the agriculture year 2016-2017.

\section{Analytical tools}

Tabular analysis- The formula to estimate this average is given below:

\section{Arithmetic mean $=\quad \sum X / n$}

The following formula was used for calculating the weighted average of different items.

Weighted average $=\frac{\mathrm{W}_{1} \mathrm{X}_{1}+\mathrm{W}_{2} \mathrm{X}_{2}+\ldots \ldots \ldots+\mathrm{W}_{\mathrm{n}} \mathrm{X}_{\mathrm{n}}}{\mathrm{W}_{1}+\mathrm{X}_{2}+\ldots \ldots+\mathrm{W}_{\mathrm{n}}}$

Where, $X_{i}=$ Weighted value of an ith item

$$
\begin{aligned}
& \mathrm{W}_{\mathrm{i}}=\text { Weight of } \mathrm{X}_{1} \\
& \mathrm{~W}_{\mathrm{n}}=\mathrm{N}=\text { total weight }
\end{aligned}
$$

Percentage $=$ Simple comparisons have been made on the basis of percentage.

\section{Cost concept}

Cost $\mathbf{A}_{1}=$ Value of purchased material inputs (seed, insecticides and pesticides, manure, 
fertilizer),hired human labour, hired farm machinery, irrigation charges and interest on working capital.

$\operatorname{Cost} \mathbf{A}_{2}=$ Cost $\mathrm{A}_{1}+$ rent paid for leasedin Land.

Cost $\mathbf{B}_{1}=$ Cost $\mathrm{A}_{2}+$ interest on value of owned capital assets (excluding land).

$\operatorname{Cost} \mathbf{B}_{2}=$ Cost $\mathrm{B}_{1}+$ rental value of owned land (net of land revenue) and rent paid for leased-in land.

Cost $\mathbf{C}_{1}=$ Cost $\mathrm{B}_{1}+$ Imputed value of Family Labour.

Cost $\mathbf{C}_{2}=$ Cost $\mathrm{B}_{2}+$ Imputed value of Family Labour.

Cost $\mathbf{C}_{\mathbf{3}}=10 \%$ of Cost $\mathrm{C}_{2}$ as managerial $\cos t+\cos t \mathrm{C}_{2}$.

The gross income, net income, family labour income, farm business income, farm investment income, Production per quintal and benefit cost ratio were also worked out using different profitability concepts.

\section{Results and Discussion}

Wheat is an important crop of the study area. It occupied 40.40 per cent of the total cropped area on sample farms. The cost incurred on wheat production on different size group of farms has been worked out in table 1 .

The different cost components viz. hired human labour, family labour, machine labour, seed cost, plant protection materials, fertilizer, interest on working capital, land revenue, rental value of owned land, depreciation and interest on fixed capital were taken into consideration for the study. The average total cost of cultivation of wheat production was workout to Rs. 53291.16, varying from Rs. 49900.00 to Rs. 56542.27 per hectare on different size group of farms. The variation in input cost on farm was due to variation in use of production input, which was found higher on large farms as compared to marginal and small farms due to more use of inputs like tractor power, fertilizer, seed, irrigation etc. Amongst input items, human labour accounted for the highest share of 13.14 per cent followed by manure \& fertilizer 10.95 per cent, tractor power 8.32 per cent, seed 7.88 per cent and irrigation 6.22 per cent to the total cost, keeping rental value as constant on all size groups of farms.

\section{Yield and cost of production}

As regards to the income structure from wheat cultivation at different size group of farms were concerned in the study area, it is observed from the table 2 that an overall, farmer gained yield of $35.34 \mathrm{qtl} / \mathrm{ha}$ at their farm, which was found to be maximum on large farms (38.33 qtl/ha) followed by small farms (35.50 qtl/ha) and marginal farms (32.20 qtl/ha). The average gross income was found to be Rs. 92406.25 and net income of Rs. 39115.09 per hectare however, the net income varied from Rs.34474.92 on marginal farms to Rs. 43113.98 on large farms due to variation in yields, which was due to variations in use of production input. The higher use of production inputs and better management of the large farms resulted in higher yield and income of their farms. The average cost of production per quintal came to Rs.1509.98 which varies from Rs.1549.69 on marginal farms to Rs. 1475.14 on large farms; the cost of production per quintal was higher on marginal farms due to poor management, awareness and improper use of resources. The input-output ratio was higher on large farms (1:1.76) fallowed by small farms (1:1.74) and marginal farms (1:1.69).

\section{Cost concept}

Table 3 revealed that the cost of cultivation of wheat was estimated under various cost concepts like as Cost A1, Cost A2, Cost B1, Cost B2, Cost C1, Cost C2 and Cost C3. Table 3 portrays that average cost $A_{1}, A_{2}, B_{1}$, 
$\mathrm{B}_{2}, \mathrm{C} 1, \mathrm{C} 2, \mathrm{C}_{3}$ were observed to Rs. The cost $\mathrm{C}_{3}$ was observed to be higher on 22850.83, Rs. 22850.83, Rs. 35849.49, Rs. large farms as Rs 62196.50 fallowed by Rs 49849.49, Rs. 39291.16, Rs. 53291.16 and 58774.23 on small farms and Rs 54890.08 on Rs. 58620.27on sample farms respectively. marginal farms.

Table.1 Total cost of cultivation and its brake up of Wheat

\begin{tabular}{|c|c|c|c|c|c|}
\hline \multirow{2}{*}{$\begin{array}{l}\text { S. } \\
\text { No. }\end{array}$} & \multirow[t]{2}{*}{ Particulars } & \multicolumn{3}{|c|}{ Size groups of farms } & \multirow[t]{2}{*}{ Average } \\
\hline & & 0-1 ha. & 1-2 ha. & $2 \&$ above & \\
\hline (A) & \multicolumn{4}{|l|}{ Operational cost } & \\
\hline 1. & Human labour & $\begin{array}{c}6125.00 \\
(12.27)\end{array}$ & $\begin{array}{c}7000.00 \\
(13.10)\end{array}$ & $\begin{array}{c}7875.00 \\
(13.93)\end{array}$ & $\begin{array}{c}7000.00 \\
(13.14)\end{array}$ \\
\hline a. & Family labour & $\begin{array}{c}3500.00 \\
(7.01)\end{array}$ & $\begin{array}{c}3675.00 \\
(6.88)\end{array}$ & $\begin{array}{c}3150.00 \\
(5.57)\end{array}$ & $\begin{array}{c}3441.67 \\
(6.46)\end{array}$ \\
\hline b. & Hired labour & $\begin{array}{c}2625.00 \\
(5.26)\end{array}$ & $\begin{array}{c}3325.00 \\
(6.22)\end{array}$ & $\begin{array}{c}4725.00 \\
(8.36)\end{array}$ & $\begin{array}{c}3558.33 \\
(6.68)\end{array}$ \\
\hline 2. & Tractor power & $\begin{array}{c}4250.00 \\
(8.52)\end{array}$ & $\begin{array}{c}4450.00 \\
(8.33)\end{array}$ & $\begin{array}{c}4600.00 \\
(8.14)\end{array}$ & $\begin{array}{c}4433.33 \\
(8.32)\end{array}$ \\
\hline 3. & Manure \& Fertilizer & $\begin{array}{c}5312.80 \\
(10.65)\end{array}$ & $\begin{array}{c}5875.70 \\
(11.00)\end{array}$ & $\begin{array}{c}6312.80 \\
(11.16)\end{array}$ & $\begin{array}{c}5833.77 \\
(10.95)\end{array}$ \\
\hline 4. & Seed & $\begin{array}{c}3600.00 \\
(7.21)\end{array}$ & $\begin{array}{c}4500.00 \\
(8.52)\end{array}$ & $\begin{array}{c}4500.00 \\
(7.96)\end{array}$ & $\begin{array}{c}4200.00 \\
(7.88)\end{array}$ \\
\hline 5. & Irrigation & $\begin{array}{c}2840.00 \\
(5.69)\end{array}$ & $\begin{array}{c}3260.00 \\
(6.10)\end{array}$ & $\begin{array}{c}3840.00 \\
(6.79)\end{array}$ & $\begin{array}{c}3313.33 \\
(6.22)\end{array}$ \\
\hline 6. & Plant protection & $\begin{array}{c}702.00 \\
(1.41)\end{array}$ & $\begin{array}{c}747.00 \\
(1.40)\end{array}$ & $\begin{array}{l}769.00 \\
(1.36)\end{array}$ & $\begin{array}{c}739.33 \\
(1.39)\end{array}$ \\
\hline \multirow[t]{2}{*}{7.} & Interest on working capital & $\begin{array}{c}676.54 \\
(1.36)\end{array}$ & $\begin{array}{c}775.52 \\
(1.45)\end{array}$ & $\begin{array}{c}866.14 \\
(1.53)\end{array}$ & $\begin{array}{l}772.73 \\
(1.45)\end{array}$ \\
\hline & Total operational cost & $\begin{array}{c}23506.34 \\
(47.11)\end{array}$ & $\begin{array}{c}26608.22 \\
(49.80)\end{array}$ & $\begin{array}{c}28762.94 \\
(50.87)\end{array}$ & $\begin{array}{c}26292.50 \\
(49.34)\end{array}$ \\
\hline B. & Rental value of land & $\begin{array}{c}14000.00 \\
(28.06)\end{array}$ & $\begin{array}{c}14000.00 \\
(26.20)\end{array}$ & $\begin{array}{c}14000.00 \\
(24.76)\end{array}$ & $\begin{array}{c}14000.00 \\
(26.27)\end{array}$ \\
\hline C. & \multicolumn{4}{|c|}{ Over head cost } & \\
\hline 1. & Interest on fixed capital & $\begin{array}{c}6196.87 \\
(12.42)\end{array}$ & $\begin{array}{c}6411.45 \\
(12.00)\end{array}$ & $\begin{array}{c}6939.66 \\
(12.76)\end{array}$ & $\begin{array}{c}6515.99 \\
(12.23)\end{array}$ \\
\hline 2. & Repairs of dead stock & $\begin{array}{c}3718.12 \\
(7.45)\end{array}$ & $\begin{array}{c}3846.87 \\
(7.20)\end{array}$ & $\begin{array}{c}4103.80 \\
(7.26)\end{array}$ & $\begin{array}{c}3889.60 \\
(7.30)\end{array}$ \\
\hline \multirow[t]{3}{*}{3.} & Depreciation & $\begin{array}{c}2478.75 \\
(4.97)\end{array}$ & $\begin{array}{c}2564.58 \\
(4.80)\end{array}$ & $\begin{array}{c}2735.87 \\
(4.84)\end{array}$ & $\begin{array}{c}2593.07 \\
(4.87)\end{array}$ \\
\hline & Total over head cost & $\begin{array}{c}12393.74 \\
(24.84)\end{array}$ & $\begin{array}{c}12822.90 \\
(24.00)\end{array}$ & $\begin{array}{c}13779.33 \\
(24.84)\end{array}$ & $\begin{array}{c}12998.66 \\
(24.39)\end{array}$ \\
\hline & Total cost & $\begin{array}{l}49900.00 \\
(100.00)\end{array}$ & $\begin{array}{l}53431.12 \\
(100.00)\end{array}$ & $\begin{array}{l}56542.27 \\
(100.00)\end{array}$ & $\begin{array}{c}53291.16 \\
(100.00)\end{array}$ \\
\hline
\end{tabular}

(Figures in bracket show the percentage of respective value) 
Table.2 Total returns received from wheat

\begin{tabular}{|l|l|c|c|c|c|}
\hline \multicolumn{7}{|c}{} & \multicolumn{3}{c}{ (Rs/ha) } \\
\hline S. & Particulars & \multicolumn{3}{c|}{ Size groups of farms } & Average \\
\cline { 2 - 5 } No & & $\mathbf{0 - 1}$ ha. & $\mathbf{1 - 2}$ ha. & $\mathbf{2 ~ \& ~ a b o v e ~}$ & \\
\hline 1. & Input cost & 49900.08 & 53431.12 & 56542.27 & 53291.16 \\
\hline 2. & Total yield in qtl/ha. & 32.20 & 35.50 & 38.33 & 35.34 \\
\hline 3. & Yield of by product qt1/ha. & 64.10 & 71.00 & 74.74 & 69.95 \\
\hline 4. & Rate of main product (in Rs/qtl.) & 1625.00 & 1625.00 & 1625.00 & 1625.00 \\
\hline 5. & Rate of by product (in Rs/qtl.) & 500.00 & 500.00 & 500.00 & 500.00 \\
\hline 6. & Gross Income (main + by product) & 84375.00 & 93187.50 & 99656.25 & 92406.25 \\
\hline 7. & Net Income & 34474.92 & 39756.38 & 43113.98 & 39115.09 \\
\hline 8. & Cost of production/qtl. & 1549.69 & 1505.10 & 1475.14 & 1509.98 \\
\hline 9. & Input-output ratio & $1: 1.69$ & $1: 1.74$ & $1: 1.76$ & $1: 1.73$ \\
\hline
\end{tabular}

Table.3 Total cost according to different cost concept

\begin{tabular}{|c|c|c|c|c|c|}
\hline \multirow{2}{*}{ S.No. } & \multirow{2}{*}{ Particulars } & \multicolumn{3}{|c|}{ Size groups of farms } & \multirow{2}{*}{ Average } \\
\hline & & 0-1 ha. & 1-2 ha. & $2 \&$ above & \\
\hline $\mathbf{1}$ & Cost $A_{1}$ & 20006.34 & 22933.22 & 25612.94 & 22850.83 \\
\hline 2 & Cost $A_{2}$ & 20006.34 & 22933.22 & 25612.94 & 22850.83 \\
\hline 3 & Cost $\mathrm{B}_{1}$ & 32400.08 & 35756.12 & 39392.27 & 35849.49 \\
\hline 4 & Cost $\mathrm{B}_{2}$ & 46400.08 & 49756.12 & 53392.27 & 49849.49 \\
\hline 5 & Cost $C_{1}$ & 35900.08 & 39431.12 & 42542.27 & 39291.16 \\
\hline 6 & Cost $\mathrm{C}_{2}$ & 49900.08 & 53431.12 & 56542.27 & 53291.16 \\
\hline 7 & Cost $C_{3}$ & 54890.08 & 58774.23 & 62196.50 & 58620.27 \\
\hline
\end{tabular}

Table.4 Size group wise gross income, net income, family labour income, farm business income and far investment income

\begin{tabular}{|l|l|c|c|c|c|}
\hline S. & Particulars & \multicolumn{3}{|c}{ Size groups of farms } & Average \\
\cline { 2 - 5 } No & & $\mathbf{0 - 1}$ ha. & $\mathbf{1 - 2}$ ha. & $\mathbf{2 ~ \& ~ a b o v e ~}$ & \\
\hline $\mathbf{1}$ & Gross income & 84375.00 & 93187.50 & 99656.25 & 92406.25 \\
\hline $\mathbf{2}$ & Net income & 34474.92 & 39756.38 & 43113.98 & 39148.43 \\
\hline $\mathbf{3}$ & Family labour income & 37974.92 & 43431.38 & 46263.98 & 42556.76 \\
\hline $\mathbf{4}$ & Farm business income & 64368.66 & 70254.28 & 74043.31 & 69555.42 \\
\hline $\mathbf{5}$ & Farm investment income & 60868.66 & 66579.28 & 70893.31 & 66113.75 \\
\hline
\end{tabular}

\section{Income measures approach}

Income measures approach is a crucial total of estimating the degree of farm business achievements. It guides to farmers about success of farm enterprises, efficiency and productivity of resources. It is also helpful in decision making, organization and separation of the farms income as a gross income, Net income, family labour income, farm business income, and farm investment income are the key components of income measures approach.

Table 4 reveals that the average family labour income was Rs 42556.76, however, family labour income varied from Rs 37974.92 on marginal farms to Rs 46263.98 on large 
farms. The farm business income was higher on large farms as Rs 74043.31 fallowed bye Rs 70254.28 on small farms and Rs 64368.66 on marginal farms. The average farm investment income was found to be Rs 66113.75

It is concluded that the cost of wheat cultivation as quoted earlier, cost C3 was noted highest in case of large farms (62196.50 $\mathrm{Rs} / \mathrm{ha})$ followed by small farms (58774.23 Rs/ha) and marginal farms (54890.08 Rs/ha) in which cost A1 was also found highest on large farms (25612.94 Rs/ha) in comparison to small farms (22933.22 Rs/ha) and marginal farms (20006.34 Rs/ha). The productivity was to be found highest in case of large farms (38.33qtl/ha) as compared to small farms (35.50qtl/ha) and marginal farms (32.20qtl/ha). The gross income was observed highest from the cultivation of wheat on large farms (99656.25 Rs/ha) as compared to small farms (93187.50 Rs/ha) and marginal farms $(84375.00 \mathrm{Rs} / \mathrm{ha})$. The net income, farm business income and farm investment income was noticed high on large farms as compared to medium and small farms while benefit cost ration was found to be highest in case of large farms (1:1.76) followed by small farms (1:1.74) and marginal farms (1:1.69).

\section{References}

Ahirwar, Pratibha (2015). Economics analysis of mixed farming system for upliftment of socio economic status of small and marginal farmers in Indore district of Madhya Pradesh. M.Sc. (Ag.) Thesis submitted to Rajmata Vijayaraja Scindiya Krishi Viswa Vidyalaya, Gwalior.

Mekuria, Wuletaw and Mekonnen, Kindu. (2018). Determinants of crop-livestock diversification in the mixed farming systems: Evidence from central highlands of Ethiopia. Agriculture \& Food Security. 7. 10.1186/s40066-018-0212-2.

Nizamuddin Khan and Ashish Kumar Parashari(2018). "Income and Employment Generation through Integrated CropLivestock Farming System in Bulandshahr District: A Geographical Analysis". Acta Scientific Agriculture 2.5, 36-39.

Pomi Shahbaz, Ismet Boz, Shamsheer ul Haq, and Umer Bin Khalid (2017). "Mixed Farming and its impact on Farm Income; A study in District Faisalabad, Punjab Pakistan". IJRDO-Journal of Agriculture and Research Volume-3, Issue-8 Paper-2.

Ramrao, W. Y., Tiwari, S. P., Saraswat, S. S., Pathak, R., Gupta, R. (2008). Integration of crop-livestock-poultry-duck farming system by large farmers in the Plain tribal areas of Chhattisgarh in Central India. CIPAV Foundation, Cali, Colombia, Livestock Research for Rural Development, 20, 3, pp 42 ,

Tare, Amit (2011). A study on optimum combination of crop and livestock enterprise in Dewas Madhya Pradesh. M.Sc. (Ag.) Thesis submitted to Rajmata Vijayaraja Scindiya Krishi Viswa Vidyalaya, Gwalior.

Thornton, Philip K., and M. Herrero (2001). "Integrated crop-livestock simulation models for scenario analysis and impact assessment". Agricultural systems 70.2-3: 581-602

\section{How to cite this article:}

Ramratan Singh, Babu Singh, Jyoti Gupta and Ramvinay Pal. 2020. Economics of Wheat Cultivation in Jaunpur and Ghazipur districts of Eastern Uttar Pradesh. Int.J.Curr.Microbiol.App.Sci. 9(10): 2256-2261. doi: https://doi.org/10.20546/ijcmas.2020.910.273 